\title{
MUTAGENIC EFFECTS OF GAMMA IRRADIATION ON OIL PALM (Elaeis guineensis Jacq.) SEEDLING GERMINATION AND GROWTH
}

\section{DICKSON OSEI DARKWAH*; ESSIE T BLAY**; HARRY M AMOATEY;; DANIEL AGYEI-DWARKO*; ENOCH SAPEY* and MEILINA ONG-ABDULLAH ${ }^{\ddagger}$}

\begin{abstract}
Mutation induction has been used to generate genetic variability in most crop plants. This research was conducted to assess genetic variation induced by gamma radiation on the various treatment designated as $M_{1^{\prime}} M_{2^{\prime}} M_{2} M_{1}$ at $10 \mathrm{~Gy}$. A randomised complete block design with four replicates was used for the experiment. Parameters such as percentage germination, root length, leaf area, plant height and stem/trunk circumference were taken from 4- to 12-month seedlings after planting. Data was analysed using GenStat (12 ${ }^{\text {th }}$ edition), which revealed significant differences in germination and growth of these oil palm seedlings. The study shows that percentage germination as well as growth parameters were stimulated in the $M_{1}$ seedlings but inhibited in the $M_{2}$ and $M_{2} M_{1}$ populations.
\end{abstract}

Keywords: mutation breeding, dose, genetic variability, improvement.

Date received: 26 September 2018; Sent for revision: 30 September 2018; Received in final form: 3 March 2019; Accepted: 30 April 2019.

\section{INTRODUCTION}

The high yields, low cost, and stability of palm oil makes it the most widely used vegetable oil in the world, and global production of the commodity is steadily rising in response to population growth and policies that promote the use of palm and other oils in biofuels (Petrenko et al., 2016). Its rapid growth has also drawn negative attention that requires the industry to manage public sensitivities especially in issues pertaining to health and environment, and to swiftly address them to ensure that the industry's competitive edge is not jeopardised (Kushairi et al., 2017). Regardless of the sentiment, the palm oil is still the largest internationally traded vegetable

* CSIR-Oil Palm Research Institute, P. O. Box 74, Kade, Ghana.

** Crop Science Department, University of Ghana,

P. O. Box LG 25, Legon, Accra, Ghana.

‡ Ghana Atomic Energy Commission, P. O. Box LG 80, Legon, Accra, Ghana.

\# Malaysian Palm Oil Board, 6 Persiaran Institusi, Bandar Baru Bangi, 43000 Kajang, Selangor, Malaysia. E-mail: meilina@mpob.gov.my oil with demand estimated to reach 240 million tonnes by 2050 (Corley, 2009). Restricted genetic base of the oil palm coupled with the long breeding cycle generally result in a slow genetic progress from one cycle of selection to another, hampering significant improvement of the crop. According to Wonkyi-Appiah (2013), new sources of variation need to be introduced into the oil palm breeding programme to enhance selection for high yields and other useful traits. Aside from leveraging the genetic resources (Rajanaidu et al., 2017), Kushairi et al. (2017) introduced the concept of transformative technologies providing the relevant tools to further enhance research. These technologies continue to improve over time and as more successful applications in the plant system are reported (Kushairi et al., 2018), this will provide the impetus for commodity crop such as the oil palm to leverage these advancements.

One of the ways of accelerating oil palm breeding and development of novel traits is by mutation induction. Although not a new technology, it is still very relevant. According to Roychowdhury and Tah 
(2013), mutation in crop species can significantly increase genetic variability and accelerate many breeding programmes. Induced mutations, using chemical or physical mutagens, is a suitable approach to producing variation in plant breeding (Hakeem et al., 2013; Roychowdhury and Tah, 2011; Domingo et al., 2007). This can produce several improved mutant varieties with high demand and economic value (Din et al., 2004). Induced mutants also have superior characters such as short stature and lodging resistance, disease resistance, improved oil quality and increased nitrogen fixation (Hakeem et al., 2013). Therefore mutation breeding through gamma irradiation may be a useful tool in creating variation in oil palm. Through a study conducted by Rohani et al. (2012), oil palm callus cultures were subjected to gamma irradiation and the subsequent clones produced were field planted. At high dosages, modifications to specific physiological and vegetative characteristics such as the biomass were observed (Samsul Kamal et al., 2014). The objectives of this study are to induce variation in oil palm using gamma irradiation and subsequently to determine its effect on seed germination and seedling growth at the nursery.

\section{MATERIALS AND METHODS}

Seeds for this experiment were obtained from $M_{1}$ population at the Oil Palm Research Institute (OPRI) in Ghana developed by Wonky-Appiah in 1976. These seeds were derived from the commercial Deli dura x Aba pisifera (Nigeria) cross. The $\mathrm{M}_{1}$ palms irradiated at 10 Gy showing superiority in yield were selected. Two thousand and one hundred $\mathrm{M}_{2}$ seeds produced under controlled pollination of the selected $\mathrm{M}_{1}$ palms were at $17 \%$ moisture content before being irradiated to produce recurrent irradiation population $\left(\mathrm{M}_{2} \mathrm{M}_{1}\right)$ at 10 Gy. Nonirradiated seeds from a commercial oil palm variety as well as irradiated seeds $\left(\mathrm{M}_{1}\right)$ of the same variety were obtained from the Plant Breeding Division of OPRI. Part of the non-irradiated seeds was used as a control $\left(\mathrm{M}_{0}\right)$ (Table 1).

Irradiation of seeds was done at the Radiation Technology Centre of the Ghana Atomic Energy
Commission (GAEC) at a dosage of 10 Gy radiation sourced from cobalt-60.

\section{Field Experiment}

The research was carried out at the OPRI nursery. Hundred germinated seeds of each treatment were sown singly in black polybags $(35.6 \mathrm{~cm} \times 45.7 \mathrm{~cm})$ filled with a mixture of topsoil and sand at the ratio of 2:1 (Wonky-Appiah, 1976).

A randomised complete block design (RCBD) was established for the experiment involving four treatments with four replications and 25 plants per plot. Standard cultural practices were carried out accordingly. Root length was determined nondestructively at three months after planting (MAP). Plant height, butt circumference and leaf area were recorded monthly from 4 to 12 MAP on 10 palms randomly selected from each plot (treatment).

Germination frequency was determined by the formula:

$$
\begin{aligned}
& \text { Germination } \\
& \text { percentage }(\%)
\end{aligned}=\frac{\text { Germinated seeds }}{\begin{array}{c}
\text { Total seeds sent for } \\
\text { germination }
\end{array}} \times 100
$$

\section{Root Length (cm)}

This was determined at 3 MAP. Polybags with seedlings were soaked with water to allow easy removal of ball of soil around the root. A piece of thread was laid alongside the longest root and its equivalent length on a meter rule taken as the reading.

\section{Number of Leaves Per Plant}

This was determined by counting the number of leaves on a seedling on a monthly basis from 4 to 12 MAP.

\section{Plant Height $(\mathrm{cm})$}

This was measured as height from the soil level in the polybag to the tip of the highest leaf using a meter rule at monthly intervals from 4 to 12 MAP.

TABLE 1. IRRADIATION TREATMENTS APPLIED ON OIL PALM SEEDS

\begin{tabular}{lccc}
\hline Treatments & Designation & $\begin{array}{c}\text { Dosage (Gy) } \\
\text { of irradiation }\end{array}$ & $\begin{array}{c}\text { Quantity of seed } \\
\text { for germination }\end{array}$ \\
\hline Commercial seed not irradiated & $\mathrm{M}_{0}$ & 0 & 500 \\
Commercial seed that is irradiated & $\mathrm{M}_{1}$ & 10 & 2100 \\
Selfed $\mathrm{M}_{1}$ seeds & $\mathrm{M}_{2}$ & 10 & 2100 \\
Re-irradiated $\mathrm{M}_{2}$ seeds (recurrent irradiation) & $\mathrm{M}_{2} \mathrm{M}_{1}$ & 10 & 2100 \\
\hline
\end{tabular}

Note: Eighty seeds of each treatment were used for routine moisture content and viability test. Seeds were germinated using the dry heat method (Hartley, 1988) for three to four months. 


\section{Butt Circumference (cm)}

Butt circumference was determined monthly by using a pair of veneer callipers to measure the diameter at two places on the butt. The circumference was determined by the formula $\pi \mathrm{d}$ where $\pi$ was taken as 3.14 and $d$ is the average diameter measured.

\section{Leaf Area $\left(\mathrm{cm}^{2}\right)$}

A non-destructive method was used. The length and greatest width of each leaf was measured with a ruler on each of the recorded plants sampled per plot. Leaf area was then estimated according to the formula by Hardon et al. (1969).$$
\text { A - b (nlw) }
$$

where:

A - leaf area. $\quad b$ - correction factor (0.57).

$\mathrm{n}$ - number of leaves.

$1 w$ - is mean of length and width of sample of the six largest leaflet.
}

GenStat software was used to generate analysis of variance (ANOVA) for the data collected. Where significant differences were observed between treatments, the Least Significant Differences (LSD) at $\mathrm{P}=0.05$ was used to separate the means.

\section{RESULTS}

\section{Effects of Gamma Irradiation on Growth and Development of Oil Palm Seedlings}

Figure 1 shows percent germination of oil palm seeds following irradiation treatments. Germination percentage was highest in $\mathrm{M}_{1}(93.22 \%)$ followed by $\mathrm{M}_{0}(79.52 \%), \mathrm{M}_{2}(70.35 \%)$ and $\mathrm{M}_{2} \mathrm{M}_{1}(10.74 \%)$.

Effect of gamma irradiation on root system (below ground structures) at $3 \mathrm{MAP}$. The mean root lengths of seedlings of the various treatments at $3 \mathrm{MAP}$ are displayed in Table 2. There were significant differences $(\mathrm{P} \geq 0.05)$ in mean root length at 3 MAP. All the irradiated materials had longer roots than the control.
Effect of gamma irradiation on shoot system (above ground structures) at 4-12 MAP. Table 3 shows the mean leaf area from 4-12 MAP for the various treatments. Significant differences $(\mathrm{P} \leq 0.05)$ occurred between $M_{0^{\prime}} M_{2}$ and $M_{2} M_{1}$ but not $M_{1}$. Though significant difference did not occur between $M_{1}$ and $M_{0^{\prime}}$ highest values were recorded in the $M_{1}$ treatment.

Significant differences at $\mathrm{P} \leq 0.05$ for plant height were observed among the treatments (Table 4) with $M_{1}$ been the tallest followed by $M_{0}, M_{2}$ and $\mathrm{M}_{2} \mathrm{M}_{1}$ in that order for all the recorded months. At four months after planting, significant difference occurred between $M_{2}$ and $M_{2} M_{1}$ but in the subsequent months $\mathrm{M}_{2}$ seedlings remained taller than $M_{2} M_{1}$ seedlings even though the differences were less obvious.

There was no significant difference at $\mathrm{P} \leq 0.05$ among the treatments with respect to butt circumference until the eight month (Table 5). Although significant difference was not observed, $\mathrm{M}_{1}$ seedlings generally had the largest butt from the

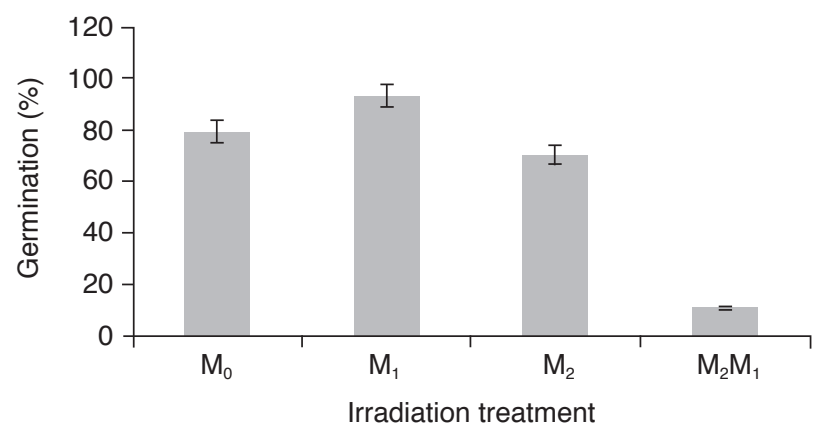

Figure 1. Percentage germination of irradiated oil palm seeds.

TABLE 2. MEAN ROOT LENGTH OF OIL PALM SEEDLINGS AT THREE MONTHS AFTER PLANTING (MAP)

\begin{tabular}{cc}
\hline Treatments & Mean root length $(\mathbf{c m})$ \\
\hline$M_{0}$ & $22.75^{c}$ \\
$M_{1}$ & $38.38^{\mathrm{a}}$ \\
$\mathrm{M}_{2}$ & $26.36 \mathrm{~b}^{\mathrm{c}}$ \\
$\mathrm{M}_{2} \mathrm{M}_{1}$ & $29.05^{\mathrm{b}}$ \\
\hline
\end{tabular}

Note: Means with the same letter (s) are indicative of no significant difference at a $5 \%$ probability level.

TABLE 3. INFLUENCE OF GAMMA IRRADIATION ON MEAN LEAF AREA OF SEEDLINGS FROM 4-12 MONTHS AFTER PLANTING (MAP)

\begin{tabular}{|c|c|c|c|c|c|c|c|c|c|}
\hline \multirow{2}{*}{ Treatments } & \multicolumn{9}{|c|}{ Months after planting } \\
\hline & 4 & 5 & 6 & 7 & 8 & 9 & 10 & 11 & 12 \\
\hline $\mathrm{M}_{0}$ & $119.42^{\mathrm{bc}}$ & $179.00^{\mathrm{b}}$ & $333.00^{b}$ & $807.00^{\mathrm{ab}}$ & $1167.00^{\mathrm{ab}}$ & $1709.21^{\mathrm{ab}}$ & $2250.00^{a}$ & $3000.12^{\mathrm{a}}$ & $4903.21^{a}$ \\
\hline $\mathrm{M}_{1}$ & $154.31^{\mathrm{a}}$ & $229.00^{a}$ & $389.00^{\mathrm{a}}$ & $1042.00^{\mathrm{a}}$ & $1491.00^{\mathrm{a}}$ & $2110.23^{a}$ & $2585.00^{a}$ & $3344.61^{\mathrm{a}}$ & $5498.02^{a}$ \\
\hline $\mathrm{M}_{2}$ & $91.61^{c}$ & $160.00^{\mathrm{b}}$ & $281.00^{b}$ & $596.00^{\mathrm{b}}$ & $914.00^{b}$ & $1293.11^{b c}$ & $1626.00^{\mathrm{b}}$ & $2216.54^{b}$ & $3473.10^{\mathrm{b}}$ \\
\hline $\mathrm{M}_{2} \mathrm{M}_{1}$ & $85.00^{c}$ & $130.00^{\mathrm{b}}$ & $218.00^{b}$ & $499.00^{\mathrm{b}}$ & $720.00^{b}$ & $1009.15^{\mathrm{b}}$ & $1255.00^{b}$ & $1703.07^{b}$ & $2589.03^{b}$ \\
\hline
\end{tabular}

Note: Means with the same letter (s) are indicative of no significant difference at a 5\% probability level. 
TABLE 4. EFFECTS OF GAMMA IRRADIATION ON MEAN PLANT HEIGHT FROM 4-12 MONTHS AFTER PLANTING

\begin{tabular}{|c|c|c|c|c|c|c|c|c|c|}
\hline \multirow{2}{*}{ Treatments } & \multicolumn{9}{|c|}{ Months after planting } \\
\hline & 4 & 5 & 6 & 7 & 8 & 9 & 10 & 11 & 12 \\
\hline $\mathrm{M}_{0}$ & $23.93^{a}$ & $25.84^{\mathrm{a}}$ & $29.81^{\mathrm{a}}$ & $38.77^{a}$ & $46.07^{a}$ & $53.20^{\mathrm{a}}$ & $60.40^{a}$ & $68.8^{a}$ & $86.4^{\mathrm{a}}$ \\
\hline $\mathrm{M}_{1}$ & $26.00^{\mathrm{a}}$ & $27.28^{\mathrm{a}}$ & $32.77^{a}$ & $43.13^{a}$ & $49.85^{a}$ & $57.30^{a}$ & $65.70^{a}$ & $72.7^{a}$ & $91.7^{\mathrm{a}}$ \\
\hline $\mathrm{M}_{2}$ & $20.66^{b}$ & $21.24^{\mathrm{b}}$ & $24.91^{\mathrm{b}}$ & $31.10^{\mathrm{b}}$ & $37.00^{\mathrm{b}}$ & $43.50^{\mathrm{b}}$ & $50.70^{\mathrm{b}}$ & $54.8^{\mathrm{b}}$ & $70.2^{\mathrm{b}}$ \\
\hline $\mathrm{M}_{2} \mathrm{M}_{1}$ & $19.91^{\mathrm{b}}$ & $20.27^{b}$ & $22.52^{\mathrm{b}}$ & $27.98^{b}$ & $32.78^{b}$ & $37.60^{\mathrm{b}}$ & $43.3^{b}$ & $47.7^{\mathrm{b}}$ & $59.6^{\mathrm{b}}$ \\
\hline
\end{tabular}

Note: Means with the same letter (s) are indicative of no significant difference at a $5 \%$ probability level.

TABLE 5. EFFECTS OF GAMMA IRRADIATION ON MEAN BUTT CIRCUMFERENCE 4-12 MONTHS AFTER PLANTING (MAP)

\begin{tabular}{|c|c|c|c|c|c|c|c|c|c|}
\hline \multirow[t]{2}{*}{ Treatments } & \multicolumn{9}{|c|}{ Months after planting } \\
\hline & 4 & 5 & 6 & 7 & 8 & 9 & 10 & 11 & 12 \\
\hline $\mathrm{M}_{0}$ & $3.02^{\mathrm{a}}$ & $3.75^{\mathrm{a}}$ & $5.27^{a}$ & $6.19^{\mathrm{a}}$ & $8.88^{a}$ & $10.68^{\mathrm{ab}}$ & $11.29^{\mathrm{b}}$ & $14.61^{\mathrm{a}}$ & $20.79^{\mathrm{ab}}$ \\
\hline $\mathrm{M}_{1}$ & $3.25^{\mathrm{a}}$ & $4.28^{\mathrm{a}}$ & $5.87^{a}$ & $7.24^{\mathrm{a}}$ & $9.56^{\mathrm{a}}$ & $11.98^{\mathrm{a}}$ & $12.90^{\mathrm{a}}$ & $15.61^{\mathrm{a}}$ & $22.64^{\mathrm{a}}$ \\
\hline $\mathrm{M}_{2}$ & $2.92^{\mathrm{a}}$ & $3.76^{a}$ & $5.16^{\mathrm{a}}$ & $5.93^{\mathrm{a}}$ & $8.16^{\mathrm{ab}}$ & $9.92^{\mathrm{b}}$ & $10.18^{\mathrm{bc}}$ & $12.86^{\mathrm{b}}$ & $18.81^{\mathrm{bc}}$ \\
\hline $\mathrm{M}_{2} \mathrm{M}_{1}$ & $2.62^{\mathrm{a}}$ & $3.29^{\mathrm{a}}$ & $4.72^{\mathrm{a}}$ & $5.28^{\mathrm{a}}$ & $7.50^{\mathrm{b}}$ & $8.70^{\mathrm{b}}$ & $8.93^{c}$ & $9.14^{\mathrm{b}}$ & $16.60^{c}$ \\
\hline
\end{tabular}

Note: Means with the same letter (s) are indicative of no significant difference at a $5 \%$ probability level.

fourth to the seventh MAP followed by $\mathrm{M}_{0^{\prime}} \mathrm{M}_{2}$ and $\mathrm{M}_{2} \mathrm{M}_{1}$ respectively. At $8 \mathrm{MAP}$, seedlings in treatment $\mathrm{M}_{1}^{2}$ had the highest butts followed by control but the difference between them were not significant. Treatments $\mathrm{M}_{2}$ and $\mathrm{M}_{2} \mathrm{M}_{1}$ however had significantly smaller butts than the former treatments.

\section{DISCUSSION}

$\mathrm{M}_{1}$ seeds which had the highest germination percentage might be due to the stimulatory effect of gamma radiation at a low dosage. Sapey (2015) in determining the optimal dose for oil palm mutation induction concluded that 9.5-11 Gy and 8-13 Gy was the optimum dose for Cross 131 and 132 respectively. Gamma irradiation dose used for the present study was 10 Gy which falls within the optimal dose for the two varieties studied by Sapey (2015) and might have accounted for the $93.22 \%$ germination.

According to Sadegh et al. (2014), low exposure of materials to gamma irradiation caused a stimulatory effect while higher exposures were inhibitory due to the reduction in mitotic activity. The cause of the stimulation might be due to hormonal changes in the plant cell, increased oxygen uptake which caused a production of organic and inorganic peroxy radicals leading to breakage of seed dormancy (Sadegh et al., 2014; Ling et al., 2008; Norfadzrin et al., 2007). In addition, Abdel-Hady et al. (2008) and Moghaddam et al. (2011) reported that the cause of the stimulation of germination at low dose of gamma irradiation might be due to ribonucleic acid (RNA) or protein synthesis activation after seed irradiation and improvement in the oxidative capability of cells leading to the reduction or domination in stress factors such as temperature and light intensity. Correspondingly, Sjodin (1962) reported that enzymatic activity as well as the awakening of young embryo may be enhanced by low doses of gamma irradiation resulting in a stimulatory effect on the rate of cell division and subsequently affecting both germination and vegetative growth.

The result of the present study is in accordance with earlier reports by various authors. WonkyiAppiah and Amu (1976) obtained up to $72 \%$ germination in oil palm seeds subjected to gamma irradiation without heat treatment. He reported that even though high doses (above 50 Gy) gave higher germination percentage, further growth at the emergence of the embryo was greatly retarded. The control (non-irradiated material) did not germinate during the experimental period of eight weeks. Kiong et al. (2010) reported that growth of citrus plant was stimulated at $10 \mathrm{~Gy}$ with increased germination percentage as compared with the control. Akshatha et al. (2013) working on the effect of gamma irradiation on germination, growth, and biochemical parameters of Terminalia arjuna Roxb concluded that low doses of gamma irradiation significantly increased the germination percentage compared to the control. Similar results were obtained by Toni et al. (2013) who studied effects of gamma irradiation in tomato seeds and reported that low doses of gamma irradiation stimulated germination, vegetative growth, number and weight of harvested fruits of tomato and that highest yield of fruits was produced at $10 \mathrm{~Gy}$. Various authors (Akshatha et al., 2013; Aynebhand and Afsharinafar, 2012; Selvaraju and Raja, 2001) have all concurred with the stimulatory effects of low doses of gamma irradiation on germination, vegetative growth and yield. 
The populations subjected to recurrent irradiation $\left(\mathrm{M}_{2} \mathrm{M}_{1}\right)$ had lower germination frequencies $(10.74 \%)$. This might be due to inhibitory effect posed by the recurrent gamma irradiation treatment. The inhibitory effect could be caused by increase in stress factors, reduced mitotic and enzymatic activities leading to low shoot and root proliferation. $\mathrm{M}_{2}$ seeds had $70.35 \%$ germination percentage which signifies that gamma irradiation had severe inhibitory effect on the recurrent irradiation population $\left(\mathrm{M}_{2} \mathrm{M}_{1}\right)$. It can therefore be deduced that low dosage of gamma irradiation provides positive stimulation for germination whilst further exposure to gamma irradiation especially when applied repeatedly have an inhibitory effect on germination as reflected in the $\mathrm{M}_{2} \mathrm{M}_{1}$ materials.

According to Tinker and Corley (2003), the dry heat method of germination should give above $85 \%$ germination. The current germination percentage with the dry heat method at CSIR-OPRI falls within the range of 79\%-82\% (Obeng Godfred, pers. comm.). All the treatments except the $\mathrm{M}_{1}$ population (93.22\%) rose above this value implying that germination of seeds could be increased by the use of low doses of gamma radiation. An increase of about $11 \%-14 \%$ in germination over the control can bring good returns to oil palm seed producers.

The stimulation of cell division and elongation by the low dose of gamma irradiation might have led to the increase in root length of $M_{1}$ seedlings. This was supported by several independent studies done on other crops. Sasikala and Kalaiyarasi (2010) reported that low dose of gamma irradiation can increase root length while high doses caused a stunted root growth in rice. Akshatha et al. (2013) also observed a similar trend in Terminalia arjuna Roxb. Gamma irradiation at 25 Gy increased the root length over the control but with doses above 25 Gy root lengths were significantly reduced. Furthermore, Ikram et al. (2010) also affirmed that gamma irradiation at low doses (15, 30 and $60 \mathrm{~Gy})$ increased significantly the root length of mung bean but beyond these there was a reduction in the root length compared to the control.

The low dose (10 Gy) of gamma irradiation might have caused the stimulation of cell division and elongation in $M_{1}$ palms leading to larger and longer leaves which ultimately increased the leaf area in the $\mathrm{M}_{1}$ palms. Ilyas and $\mathrm{Naz}$ (2014), reported significant increase in average leaf width and length after gamma irradiation at 10 Gy of Faisalabad genotype of Curcuma longa (L) which resulted in an increase in the leaf area. Islam et al. (2015) also affirmed that the leaf area of grape saplings (Vitis vinifera L.) were significantly higher at $10 \mathrm{~Gy}$ as compared to the control plants.

Gamma irradiation treatments significantly increased the plant height in the $\mathrm{M}_{1}$ population and reduced the height of $M_{2}$ and $M_{2} M_{1}$ compared to control $\left(\mathrm{M}_{0}\right)$ plants. The stimulatory effect of lower doses of gamma irradiations on growth of plants might be due to stimulation of cell division, alteration of metabolic processes that affect synthesis of nucleic acids (Ilyas and Naz, 2014). According to Mounir et al. (2015), irradiating seeds with a 20 Gy dose (low dose) prior to sowing significantly increased growth promoters gibberellic acid (GA) and auxin and insignificantly decreased growth inhibitor, abscisic acid (ABA). Grover and Khan (2014) concluded that gamma irradiation at a low dose stimulates, while a high dose inhibits plant growth and development. Grover and Khan (2014) also reported that the induced stimulation of plant growth at low dosage causes changes in the biochemical characteristics of target tissue or plants which directly or indirectly regulate cell division and cell elongation and hence the morphological aspects and consequently the related physiological attributes increase.

The results obtained in this study corroborated the findings of other authors. Grover and Khan (2014) also reported that significant differences occurred between seeds of wheat irradiated with gamma irradiation at various dosages but maximum height was obtained in wheat seeds irradiated at 10 Gy. Minisi et al. (2013) reported a significant increase in height following the application of low dose of gamma irradiation compared to the control in Moluccella laevis (L).

Though higher doses were not used in this study, recurrent irradiation through gamma rays caused inhibition effect in plant height. The reason accounting for reduction in the height of plant in the $\mathrm{M}_{2} \mathrm{M}_{1}$ and $\mathrm{M}_{2}$ population, might be due to inhibitory effect produced by the gamma irradiation due to reduced mitotic division in meristematic tissues and reduced moisture content (Khalil et al., 1986), interruption in DNA synthesis and other physiological and biochemical changes (Sasikala and Kalaiyarasi, 2010). The cause of the inhibition by high doses might be due to oxidative stress with overproduction of reactive oxygen species such as super oxide radicals $(\mathrm{O}-)$, hydroxyl radicals $(\mathrm{OH}-)$ and hydrogen peroxides $\left(\mathrm{H}_{2} \mathrm{O}_{2}\right)$, which react rapidly with almost all structural and organic molecules causing disturbance of cellular metabolism (Garcia et al., 2000). This result is in harmony with Nunoo et al. (2014) who also reported a reduction in the height of tomato plants following recurrent irradiation.

Height reduction of about $31.01 \%$ at 12 MAP in the $\mathrm{M}_{2} \mathrm{M}_{1}$ population may have a potential of producing the dwarf or semi dwarf trait. Dwarf traits are of great importance to oil palm breeders as this will extend the economic life of the palm, increase the efficiency of harvesting and as well facilitate mechanization of harvesting (Barcelos et al., 2015). The $\mathrm{M}_{2} \mathrm{M}_{1}$ seedlings may be planted for further observation. If they are found to be dwarfish, 
subsequent generations can be developed and tested for stability of the trait and possible incorporation into future breeding progamme of the OPRI.

There was no significant difference among treatments for butt circumference from the 4-7 MAP. This might be due to slow growth and development of the oil palm in initial stages. Danso et al. (2012) reported no significant differences on butt circumference and other traits from 4-7 MAP and attributed it to the inherent sluggish growth pattern of the seedlings. Significant difference occurred from the 8-12 MAP. Plants might have fully grown and were exhibiting their peak expression of this trait.

\section{CONCLUSION}

Gamma irradiation of oil palm seeds led to both stimulation and inhibition in germination and growth parameters of oil palm seedlings. Gamma irradiation led to about $14 \%$ increase in germination frequency. There was about $31.01 \%$ reduction in the height of $\mathrm{M}_{2} \mathrm{M}_{1}$ which may have a potential of introducing the dwarf trait into our breeding programme. From the results obtained on this experiment, it is clear that gamma irradiation could be a useful means of inducing variability in oil palm for the genetic improvement of the crop.

\section{ACKNOWLEDGEMENT}

The authors express their profound gratitude to OPRI for funding this research.

\section{REFERENCES}

Abdel-Hady, M S; Okasha, E M; Soliman, S S A and Talaat, M (2008). Effect of gamma radiation and gibberellic acid on germination and alkaloid production in Atropa belladonna. Australian J. Basic and Applied Science, 2(3): 401-405.

Akshatha; Chandrashekar, K R; Somashekarappa, H M and Souframanien, J (2013). Effect of gamma irradiation on germination, growth, and biochemical parameters of Terminalia arjuna Roxb. Radiation Protection Environment, 36: 38-44.

Aynebhand, A and Afsharinafar, K (2012). Effect of gamma irradiation on germination characters of amaranth seeds. European J. Experimental Biology, 2: 995-999.

Barcelos, E; Rios, S A; Cunha, R N V; Lopes, R; Motoike, S Y; Babiychuk, E; Skirycz, A and Kushnir, $S$ (2015). Oil palm natural diversity and the potential for yield improvement. Frontier Plant Science, 6: 190. DOI:10.3389/fpls.2015.00190.

Corley, R H V (2009). How much palm oil do we need? Environ. Sci. Policy, 12: 134-139. https:// doi. org/10.1016/j.envsci.2008.10.011

Danso, F; Opoku, A; Baidoo-Addo, K; Danso, I; Afari, P A and Nuertey, B N (2012). Improving the growth of oil palm seedlings with biostimulants NEB-26 and NEB-29. J. Ghana Science Association, 14(1): 46-52.

Din, R; Qasim, M and Ahmad, K (2004). Radio sensitivity of various wheat genotypes in M1 generation. International J. Agricultural Biology, 6: 898-900.

Domingo, C; Andres, F and Talon, M (2007). Rice cv. Bahia mutagenized population: A new resource for rice breeding in the Mediterranean Basin. Spanish J. Agricultural Research, 5: 341-347.

Garcia, M X U; Foote, C; Van Es, S; Devreotes, P N; Alexander, S and Alexander, H (2000). Differential developmental expression and cell type specificity of Dictyostelium catalases and their response to oxidative stress and UV-light. Biochemistry Biophysics Acta, 1492: 295-310.

Grover, S and Khan, A S (2014). Effect of ionizing radiation on some characteristics of seeds of wheat. International J. Science and Technology Research, 3: 32-33.

Hakeem, K R; Ahmad, P and Ozturk, M (2013). Crop Improvement: New Approaches and Modern Techniques. Springer Science + Business Media, New York. p. 1-16.

Hardon, J J; Williams, C N and Watson, I (1969). Leaf area and yield in the oil palm in Malaya. Experimental Agriculture, 5(01): 25-32.

Hartley, C W (1988). The Oil Palm. Longmans, London. p. 1-761.

Ikram, N; Dawar, S; Abbas, Z and Javed, Z (2010). Effect of $\left({ }^{60} \mathrm{Co}\right)$ gamma rays on growth and root rot diseases in mung bean (Vigna radiata L.). Pakistan J. Botany, 42(3): 2165-2170.

Ilyas, S and Naz, S (2014). Effects of gamma irradiation on morphological characteristics and isolation of curcuminoids and oleoresins of Curcuma longa L. The J. Animal and Plant Science, 24(5): 13691404.

Islam, A F M S; Islam, M M and Hasan, M M (2015). Effect of gamma irradiation doses on morphological 
and biochemical attributes of grape saplings. Agricultural Sciences, 6: 505-512.

Khahil, S J; Rehnan, S; Afridi, K and Jan, M T (1986). Damage induced by gamma irradiation in morphological and chemical characteristics of barley. Sarhad J. Agriculture, 2: 45-54.

Kiong, A P L; Cheng, J X O; Hussein, S and Abdul, R H (2010). Morphological and physiological responses of Orthosiphon stamineus callus to gamma irradiation at different doses. World J. Agricultural Sciences, 6(1): 58-66.

Kushairi, A; Loh, S K; Azman, I; Elina, H; OngAbdullah, M; Zanal Bidin, M N I; Razmah, G; Sundram, S and Parveez, G K A (2018). Oil palm economic performance in Malaysia and R\&D progress in 2017. J. Oil Palm Res. Vol. 30(2): 163-195. DOI: https: / / doi.org/10.21894/jopr.2018.0030.

Kushairi A; Singh, R and Ong-Abdullah, M (2017). The oil palm industry in Malaysia: Thriving with transformative technologies. J. Oil Palm Res. Vol. 29(4): 431-439. DOI: https: //doi.org/10.21894/ jopr.2017.00017.

Ling, A P K; Chia, J Y; Hussein, S and Harun, A R (2008). Physiological responses of Citrus sinensis to gamma irradiation. World Applied Sciences J., 5: 12-19.

Minisi, F A; El-Mahrouk, M E; El-Din, M; Rida, F and Nas-Mary, N (2013). Effects of gamma radiation on germination, growth characteristics and morphological variations of Moluccella laevis L. American-Eurasian J. Agricultural \& Environmental Science, 13(5): 696-704.

Moghaddam, S S; Jaafar, H; Ibrahim, R; Rahmat, A; Aziz, M A and Philip, E (2011). Effects of acute gamma irradiation on physiological traits and flavonoid accumulation of Centella asiatica. Molecules, 16(6): 4994-5007.

Mounir, A M; El-Yazid, A A; Orabi, I O A; Zahran, A A and El-Oksh, I I (2015). Effect of sowing date, gamma irradiation and inter cultivar differences on growth, pod characteristics and some endogenous plant growth regulators in snap beans. World J. Agricultural Sciences, 11(6): 380-390.

Norfadzrin, F; Ahmed, O H; Shaharudin, $\mathrm{S}$ and Rahman, D A (2007). A preliminary study on pigments and antioxidant machinery of red pepper (Capsicum annuum L.) seedlings from gamma irradiated seeds. J. Plant Biology, 47: 314-321.

Nunoo, J; Quartey, E K; Amoatey, H M and Klu, G Y P (2014). Effect of recurrent irradiation on the improvement of a variant line of wild tomato (Solanum pimpinellifolium). J. Radiation Research and Applied Sciences, 7(4): 377-383. http://doi. org/10.1016/j.jrras.2014.07.007.

Obeng Godfred (2017). Personal communication, 10 July 2017.

Petrenko, C; Paltseva, J and Searle, S (2016). Ecological impacts of palm oil expansion in Indonesia [White paper]. International Council on Clean Transportation. http://www.theicct.org/ sites / default / files / publication / Indonesia-palmoil-expansion_ICCT_july2016.pdf, accessed on 21 September 2016.

Rajanaidu, N; Kushairi, A and Mohd Din, A (2017). Monograph Oil Palm Genetic Resources. MPOB, Bangi. $289 \mathrm{pp}$.

Rohani, O; Samsul Kamal, R; Rajinder, S and MohdNazir, B (2012). Mutation induction using gamma irradiation on oil palm (Elaeis guineensis Jacq.) cultures. J. Oil Palm Res. Vol. 24: 1448-1458.

Roychowdhury, R and Tah, J (2011). Assessment of chemical mutagenic effects in mutation breeding programme for M1 generation of carnation (Dianthus caryophyllus). Research in Plant Biology, 1(4): 23-32.

Roychowdhury, R and Tah, J (2013). Mutagenesis A potential approach for crop improvement. Crop Improvement (Hakeem, K R et al., eds.). Springer Science+Business Media, LLC. p. 149-187. DOI 10.1007/978-1-4614-7028-1_4.

Sadegh, M; Rosna, M T; Ma-Ma, L; Arash, K E and Khalili, M (2014). Stimulatory effects of gamma irradiation on phytochemical properties, mitotic behaviour and nutritional composition of Sainfoin (Onobrychis viciifolia Scop.). The Scientific World J., 85403: 1-9.

Samsul Kamal, R; Mohd Roslan, M N; Tarmizi, A H; Marhalil, M and Rohani, O (2014). Field observation of clonal oil palms irradiated with gamma rays. Oil Palm Bulletin No. 68: 5-7.

Sapey, E (2015). Mutation induction in oil palm (Elaeis guineensis Jacq.) using gamma irradiation: A preliminary studies. CSIR-OPRI/TR/E.S/2015/10.

Sasikala, R and Kalaiyarasi, R (2010). Sensitivity of rice varieties to gamma irradiation. Electronic J. Plant Breeding, 1(4): 885-889.

Selvaraju, P and Raja, K (2001). Effect of gamma irradiation of seeds on germination of different 
tree species. IUFRO Joint Symposium on Tree Seed Technology, Physiology and Tropical Silviculture. Laguna, Philippines. 66 pp.

Sjodin, J (1962). Some observations in $X_{1}$ and $\mathrm{X}_{2}$ of Vicia faba L. after treatment with different mutagenesis. Hereditas, 48: 565-573.

Tinker, P B and Corley, R H (2003). The Oil Palm (Corley, R H V and Tinker, P B eds.). Oxford, UK: Blackwell Science Ltd. p. 1-608.
Toni, W A; Fritz, W; Paula, A B; Franco, S S H; José, F G and Valter, A (2013). Effects of gamma radiation in tomato seeds. International Nuclear Atlantic Conference - INAC 2013. p. 1-4.

Wonkyi-Appiah, J B (2013). Selection in the oil palm (Elaeis guineensis Jacq.). Ghana J. Agric Science, 46: 27-33.

Wonkyi-Appiah, J B and Amu, I K A (1976). Preliminary investigations into the use of gamma irradiations to induce germination in the seed of the oil palm (Elaeis guineensis Jacq.). Ghana J. Agricultural Science, 9: 235-236. 